\title{
Antonio Richieri-Costa
}

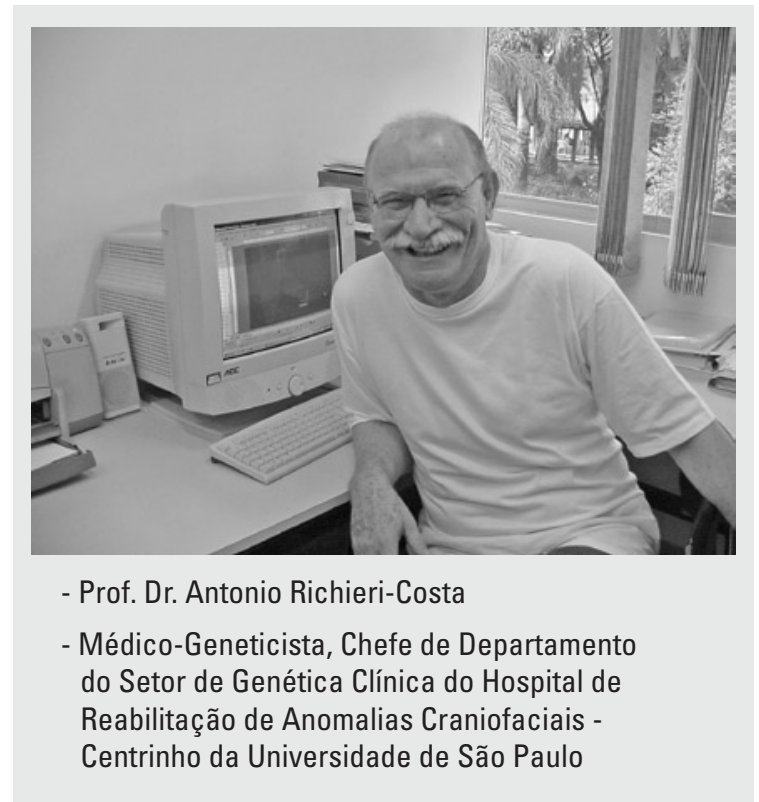

Natural de Bauru (SP), Antonio Richieri-Costa é graduado em Medicina pela Faculdade de Medicina de Botucatu - UNESP. Especialista em Neurologia e Genética, com o título de Livre-Docente na área, integra a equipe multidisciplinar do Hospital de Reabilitação de Lesões lábio-palatais da USP, onde implantou o serviço de Genética Clínica e Fonogenética.

Desde meados dos anos 70 é um pesquisador reconhecido, dentro e fora do Brasil, respeitado pela publicação de mais de uma centena de artigos. É orientador de dissertações de mestrado e teses de doutorado, desenvolvidas no Brasil e no exterior, além de coordenador do evento anual Symposium Dysmorphology and Molecular Biology: the interface, realizado em Bauru e que está em sua $3^{a}$ edição. Membro do grupo de estudos em anomalias congênitas da Organização Mundial de Saúde.

Em sua carreira docente, registra passagens pelo curso de Fonoaudiologia da FOB/USP, pela Faculdade de Medicina da UNIMAR - Universidade de Marília, pela Faculdade de Fonoaudiologia da UNESP/Marília e pela Universidade Metodista de Piracicaba - UNIMEP.Atualmente, dedica-se ao Programa de Pós-Graduação em Ciências do HRAC/USP, como docente e orientador. É fundador e editor da Revista The Brazilian Journal of Dysmorphology and Speech-Hearing Disorders - criada em 1997 no HRAC/USP.

Como pesquisador, integrou vários projetos de relevância, entre eles o Projeto Genoma - USA e coordena, no momento, uma pesquisa sobre a importância do ácido fólico na prevenção de anomalias congênitas, em conjunto com a Universidade de Iowa/USA. Sua atuante carreira cientifica the valeu indicação para o corpo de consultores/parceristas da FAPESP (Fundação de Amparo à Pesquisa do Estado de São Paulo) e CNPq (CNPq - Conselho Nacional de Desenvolvimento Científico e Tecnológico).

José Alberto de Souza Freitas (Tio Gastão)

Superintendente do HRAC/USP.

Normalmente as entrevistas da Revista Dental Press de Ortodontia e Ortopedia Facial são realizadas de forma que o entrevistado recebe por escrito as perguntas e as responde também por escrito. Esta entrevista foi realizada, no Departamento de Genética do Centrinho e depois transcrita para a forma em que está apresentada para os leitores, de acordo com os moldes clássicos do jornalismo. Foram horas de discussão e seriedade, em um clima alegre, sobre um tema palpitante. Apesar da forma coloquial do texto, houve extremo cuidado ao transcrever as palavras do entrevistado o mais fidedignamente possível. O leitor pode observar que o médico geneticista Prof. RichieriCosta foi entrevistado e muitas vezes entrevistador, deixando clara sua postura questionadora e ao mesmo tempo bem humorada, procurando disponibilizar seus conhecimentos de forma aplicada à Odontologia e ao fenômeno das reabsorções dentárias.

Alberto Consolaro 
Prof. Consolaro: Um pouco antes de o presidente Clinton anunciar solenemente o fim do seqüenciamento do genoma humano, havia um aparente "império" do DNA na determinação das características e do funcionamento do corpo humano. Atualmente algumas evidências determinaram que as células e os tecidos não funcionam assim tão simplesmente, o que o senhor tem a comentar sobre isso? O que interferiria na hereditariedade?

Prof. Richieri-Costa: Em relação ao DNA, aos genes de um modo geral, não estamos vendo nem o topo do iceberg, nem a marola que ele faz na água. Houve uma empolgação sim, enorme no princípio. Puxa vida, desvendamos o Genoma e resolvemos os problemas do ser humano... Hoje se reconhecem milhares de genes, mas ao mesmo tempo não se conhece. De alguns genes até conhecemos a ação, mas não se conhece sua ação à distância, não se conhece como funciona. Um gene pode até determinar algo, mas como ele determina isto? É um grande problema.

Prof. Consolaro: E quem gerencia a função do gene?

Prof. Richieri-Costa: $\mathrm{O}$ gene funciona como um professor. A gente sabe onde começa a ação dele, mas nunca onde termina. Você nunca sabe onde é que vai parar o que você disse dentro da classe. Como vai ser interpretado? Então sabemos o que era um bom professor? Quantos desviaram dele, quantos seguiram os passos dele? Eu comparo o gene à função de um professor.

Prof. Consolaro: Nem tudo é comandado geneticamente, o funcionamento das células e tecidos apresenta intensidades diferentes. Por que as pessoas acham que tudo funciona a partir de informações genéticas e que estas são automaticamente hereditárias? Por que as pessoas confundem as palavras: genética e hereditariedade?

Prof. Richieri-Costa: Quantos mecanismos de herança nós temos? Diversos. Cada um com seu modo de transmitir informação. Cada um com seu modo de expressar a informação. É isso que nos faz diferentes. É isso que é a diversidade.

A evolução tem um peso grande nisso tudo e foi selecionando coisas muito importantes. Por exemplo, um molar nos dias de hoje, sua localização na arcada, o número de dentes, tudo isso foi sendo modificado durante uma seleção e adaptação. Devagar e moldada pelo ambiente.

A interação filo-ambiental é fundamental. Durante milhões de anos a alimentação dos precursores da nossa espécie foi mudando e na medida que fomos virando hominídeos fomos nos adaptando. E o velho Darwin ainda explica muitas coisas.

Foi mudando todo o padrão da arcada dentária, o padrão da relação craniofacial. Então, não são só os genes determinaram o padrão de uma criatura durante a evolução. $\mathrm{O}$ ambiente também atua constantemente. $\mathrm{O}$ ambiente vai trabalhar como um arquiteto de refino. É ele quem vai refinando aquilo que nós somos.

Quer ver um exemplo que eu acho muito curioso? Com o advento da cesariana o que está acontecendo? A mulher parideira é a mulher de bacia larga. Por isso que a mulher é bonita, por isso que o corpo da mulher parece um violão, lindo. Porque durante milênios ela foi selecionada para dar a luz. $\mathrm{O}$ que acontecia com as que tinham bacia andróide, essas bacias estreitas? Morriam. Não tinha cesariana? Durante milênios a evolução foi selecionando um padrão de bacia.

Hoje com a cesariana, nós estamos selecionando as bacias estreitas também. Provavelmente daqui a cinqüenta, cem mil anos, dez mil anos, não faço idéia do tempo, nós vamos ter três tipos de mulheres. Nós vamos ter a mulher como a conhecemos hoje, com corpo arredondado, nós vamos ter os tipos "guardaroupa" e vamos ter as intermediárias. Alguém poderá perguntar: Como é que é sua mulher? Ah, a minha mulher é retona, e a sua? Oh, a minha é um violão? E sei que provavelmente nós vamos selecionar um terceiro tipo de mulher diferente. Ou estamos selecionando com a cesárea. Faz sentido. 
Prof. Consolaro: Em trabalhos clínicos são necessários heredogramas pequenos ou grandes? Qual o número de participantes familiares para que se possa confiar nos resultados? Só uma análise clínica individual seria suficiente para determinar hereditariedade?

Prof. Richieri-Costa: Na análise clínica eu prefiro heredogramas grandes para ver as nuances do fenótipo, se ele está presente ou não em pacientes levemente afetados. Porque o gene pode apresentar uma expressividade muito grande. Quando tem penetrância incompleta ocorrem aquelas nuances muito leves, que podem ser indicadoras da presença do gene. Então em trabalhos clínicos eu prefiro heredogramas grandes. Para trabalhos moleculares, de condições multifatoriais, trios são o suficiente.

Prof. Consolaro: A reabsorção dentária representa um fenômeno mediado por várias citocinas, fatores de crescimentos e produtos do ácido araquidônico, além de outros mediadores como o óxido nítrico. Em suma, a reabsorção dentária é um fenômeno análogo à reabsorção óssea. Uma maior ou menor intensidade deste tipo de reabsorção, no tratamento ortodôntico, bem variado na forma, na técnica e em vários outros fatores, poderia ser atribuída a uma hereditariedade ou mesmo a uma predisposição genética individual ou familiar? $\mathrm{Ou}$ as questões de intensidade seriam mais decorrentes de fatores ambientais?

Prof. Richieri-Costa: Essa pergunta é complexa e difícil porque são muitas variáveis. Então, isolar cada uma deve ser quase impossível. Não tem como um indivíduo ter mais óxido nítrico ou outro mediador. Mas o fenômeno não deve ser monogênico.

Prof. Consolaro: Na clínica é comum a afirmação de que todos os pacientes com movimentação ortodôntica têm reabsorção em maior ou em menor grau. Alguns querem explicar que não se colocou muita força e mesmo assim reabsorveu o dente. Alega-se que reabsorveu porque o paciente tinha um fator predisponente individual, na tentativa de se livrar da iatrogenia.

Prof. Richieri-Costa: Quando o paciente chegou, já tinha reabsorção ou não?

Prof. Consolaro: Sete a dez por cento das pessoas apresentam reabsorções dentárias sem tratamento ortodôntico.

Prof. Richieri-Costa: Sete a dez por cento! Então é uma condição da espécie humana que dez por cento tenha reabsorção dentária?

Prof. Consolaro: Sim, porque é como se fizesse parte do processo de envelhecimento. Como manchas na pele. Um certo número de pessoas em função da interação com o ambiente terá manchas na pele.

Prof. Richieri-Costa: Então é um processo de envelhecimento?

Prof. Consolaro: É uma conseqüência do uso. Eu nunca fui abordado para pensar na reabsorção dentária como processo de envelhecimento, sem uso de aparelhos.

Prof. Maria Fernanda: Então, seria natural esperar que com a idade isso aconteceria.

Prof. Consolaro: Porque se utilizam mais os dentes conforme a idade, o efeito acumulativo do tempo aumenta a chance de radiografar os dentes das pessoas sem tratamento ortodôntico e encontrar dentes com reabsorção radicular.

Prof. Richieri-Costa: Se você acompanhar pacientes dos 25 aos 50 com aconselhamento, já está introduzindo um viés! Porque você diz: olha, tem que escovar os dentes direitinho todo dia. Evite comer avelã! Evite lutar com um boxeador e coisas desse tipo. Então o fator ambiental não interferiu nesse paciente utilizado em amostra de um trabalho ortodôntico, por exemplo. 
Prof. Consolaro: Um dente com morfologia mais delicada determinada geneticamente pode sofrer reabsorção ao menor traumatismo e também durante a movimentação ortodôntica. Os dentes estão lá, com seus cementoblastos justapostos. Uma força ou traumatismo, mata os cementoblastos, o dente é exposto e começa a reabsorver. Você diria que existiu algum fator predisponente individual hereditariamente adquirido, hereditariamente recebido que facilitaria a reabsorção radicular? Um componente que faria com que em certas pessoas isso acontecesse com mais facilidade?

Prof. Richieri-Costa: O problema é o seguinte: um dente é maior, do lado existe um outro dente...eles são do mesmo tamanho, da mesma espécie.

Prof. Consolaro: Da mesma espécie sim, mas não são do mesmo tamanho, nunca são iguais.

Prof. Richieri-Costa: Mas supondo que fossem iguais e só mudasse o número de cementoblastos?

Prof. Consolaro: Na realidade vemos uma grande uniformidade, não existem relatos de variação na quantidade de cementoblastos. Pelo menos morfologicamente, isso nunca sequer foi aventado porque a intensidade e densidade destas células é igual mesmo entre pessoas diferentes. Nós não temos problemas de falta de cementoblastos na raiz.

Uma raiz conóide, por exemplo, concentra as forças recebidas mais na ponta da raiz, que é bem fininha. Outra raiz quadrangular distribui melhor a força sem sobrecarregar um único ponto do ligamento periodontal. Uma raiz proporcionalmente curta em relação à coroa vai exigir mais da camada de cementoblastos e de todo o ligamento periodontal. O que leva a crer que as reabsorções dentárias acontecem por influência dos fatores ambientais.

Prof. Richieri-Costa: Geralmente de pré-molar para trás?
Prof. Consolaro: Não, tanto faz, incisivos também tem as raízes bem delicadas. Mas para explicar a iatrogenia muitas vezes se ouve: não, eu não coloquei muita força. Não admite-se a falta de uma análise morfológica prévia ao tratamento dos dentes, que poderiam ter sido mais poupados quando mais afilados. Nesta situação se diz: este paciente tem predisposição genética hereditária à reabsorção hereditária.

Prof. Richieri-Costa: Como são os cementoblastos de um esquilo, ou de uma lontra, que roem o dia inteiro?

Prof. Maria Fernanda: Eles têm a formação incompleta da raiz dos incisivos, que roem o tempo todo. $\mathrm{O}$ ápice não forma nunca e tem erupção constante. E quando é incompleta a formação do dente fica um botãozinho de tecido mole no ápice - a papila dentária. Essa "bolinha" de tecido mole absorve bem as forças, muito melhor do que um tecido duro, como o nosso ápice. Os roedores têm um amortecedor natural no ápice da raiz.

Prof. Richieri-Costa: É muito interessante. Se não é uma alteração no número, na qualidade e na função dos cementoblastos, seria possivel que alguns cementoblastos funcionem melhor? Seria possivel uma doença primária dos cementoblastos?

Prof. Consolaro: Não. Não tem nenhuma doença conhecida ou relatada de cementoblasto. Ou pelo menos não foi identificada ainda. O que muda é a forma da raiz. Para se livrar da culpa da iatrogenia o caminho mais curto é a hereditariedade. Nas radiografias periapicais iniciais se vê a morfologia da raiz, e se for de morfologia triangular, coloca-se menos força. Mas tem que ter o trabalho de fazer radiografia para poupar o dente na ativação dos aparelhos ortodônticos. Com a consciência da importância da morfologia radicular, o Ortodontista pode antecipadamente dialogar com o paciente e explicar que a possivel reabsorção dentária durante o tratamento não é culpa dele, mas sim da morfologia radicular do paciente. 
Prof. Richieri-Costa: Bom você acabou de me dar o primeiro argumento para esquecer. Porque se o profissional não distingue uma raiz em sua morfologia, ele não distingue nada clinicamente. E o paciente perde o dente?

Prof. Consolaro: O profissional pode protelar as coisas com argumentações aceitáveis para o paciente leigo. Nos casos publicados como idiopáticos generalizados, quando se analisa criteriosamente do ponto de vista clínico pode ser detectado um fator de sobrecarga. É comum ouvir: isto é predisposição genética! Mas na realidade bastaria explicar ao paciente: no seu caso foi preciso colocar mais força, as suas raízes são mais delicadas a força matou alguns cementoblastos... Essa reabsorção da raiz faz parte do custo biológico do tratamento ortodôntico. E não achar que foi azar do paciente e dizer que ele é geneticamente deficiente.

Prof. Richieri-Costa: O que provoca reabsorção na sua visão? Bruxismo?

Prof. Consolaro: Não só, mas os traumatismos, os movimentos ortodônticos, a clareação dentária interna... algum fator externo relacionado com a etiologia da reabsorção. Em uma fase da literatura, os distúrbios endócrinos foram culpados pela reabsorção. Depois foram feitos estudos que mostraram pacientes com endocrinopatias e sem reabsorções radiculares.

Prof. Richieri-Costa: Como são os dentes dos boxeadores?

Prof. Consolaro: Não conheço estudos sobre isto. Não tem. Mas as pessoas que tem os dentes mais projetados para frente, por exemplo, sofrem mais traumatismos, batidas nos dentes e tem mais reabsorção dentária nos dentes anteriores.

Prof. Richieri-Costa: Será que é por que os dentes batem mais ou por que a forma da arcada fica muito alterada? De alguma forma pressionam os vasos, em função da força?
Prof. Maria Fernanda: E tem a pressão dos lábios, às vezes da língua.

Prof. Richieri-Costa:Tudo diminuindo a oxigenação e matando os cementoblastos.

Prof. Maria Fernanda:Uma série de fatores locais atuando concomitantemente.

Prof. Consolaro: Vou dar só um exemplo. Tira-se a força, volta tudo ao normal porque o cementoblasto torna a recobrir a raiz e pára o processo de reabsorção. Se fosse genético, continuaria indefinidamente.

Prof. Richieri-Costa: Aí se está provando que realmente é um agente externo atuando.

Prof. Consolaro: Todas as reabsorções são assim: tirou a causa que você identificou, o dente volta ao normal. Ela pára porque o cementoblasto prolifera e volta a recobrir a raiz. Não existem reabsorções continuadas ao longo da vida, você tirou aquela possível causa, ela pára. Fez tratamento ortodôntico e reabsorveu a metade das raízes, em uma eventualidade num acidente clínico, você tira a força, tira o aparelho, as raízes regularizam, os cementoblastos recobrem a superfície lesada e a pessoa vive com o dente normalmente, poupando-o no que for possivel no dia-a-dia.

Prof. Richieri-Costa: Então é uma situação primariamente ambiental.

Prof. Consolaro: Existem quatro trabalhos na literatura dizendo que a reabsorção pode ser genética ou hereditária e eles são rotineiramente usados para suportar um fator predisponente individual, uma questão hereditária. Para afastar um pouco a possibilidade de iatrogenia.

Prof. Richieri-Costa: Eu até entendo! Vamos supor que eu tenha três pacientes, com o mesmo procedimento, com o mesmo aparelho, com o mesmo dente, com a mesma força aplicada. A lesão em médio prazo 
seria a mesma nos três? Se todos os fatores fossem iguais e com a mesma força?

Prof. Consolaro: Só hipoteticamente você consegue fazer isso. Se você observar pacientes em que você extraiu um dente e movimentou o dente vizinho para o espaço, todos esses pacientes podem ter um índice de reabsorção parecido. Pelo tipo de movimento e pela extensão do movimento que se faz. Sabe-se que certos tipos de força provocam mais reabsorção, independente do paciente, porque isso já foi bem estabelecido. Os fatores ambientais são comprovados no dia-a-dia e fundamentados na literatura.

Prof. Richieri-Costa: Quando você põe força em qualquer estrutura, por mais rígida que seja, como o músculo por exemplo, ela rompe.

Prof. Consolaro: Isso. Tem um limite de resistência.

Prof. Richieri-Costa: Vai liberar cininas e fatores citotóxicos. Agora uma outra pergunta: será que, a resistência do cementoblasto é conferida geneticamente? Supondo que o meu cementoblasto se lese mais frente a 0,1 microgramas de uma cinina qualquer? Agora o seu não, o seu precisaria de um limiar maior de cinina para se lesar...

Prof. Consolaro: Os trabalhos da década de oitenta e noventa mostraram que os cementoblastos não são iguais aos osteoblastos, não obedecem aos mesmos mediadores químicos para reabsorver os dentes. Os cementoblastos não têm receptores para esses mediadores, eles são "surdos" especificamente para eles.

Prof. Richieri-Costa: São surdos! E como é que eles reabsorvem?

Prof. Consolaro: Eles não reabsorvem, só se reabsorve a raiz se tirar os cementoblastos de lá. O clasto é que se dirige para a superfície radicular sob o comando dos osteoblastos do osso vizinho.
Prof. Richieri-Costa: O cementoblasto chega a um processo de apoptose, por exemplo?

Prof. Consolaro: No dente decíduo sim, no permanente não. $\mathrm{O}$ cementoblasto do dente permanente é constantemente renovado e prolifera por um processo lento. Ele não é uma célula de proliferação muito rápida, a não ser quando induzido numa necessidade por mediadores próprios da proliferação celular.

Prof. Richieri-Costa: E como se estimula o cementoblasto?

Prof. Consolaro: Se houver uma lesão, por exemplo. Se retirar um pedacinho da camada cementoblástica, os fatores de crescimento ali presentes estimulam a proliferação deles num ritmo mais acelerado. Como acontece na ferida da pele com os fibroblastos ou com os osteoblastos em uma cirurgia óssea.

Prof. Richieri-Costa: Então ele é surdo para cinina?

Prof. Consolaro: Surdo para todos os mediadores da reabsorção óssea. Para paratormônio, calcitonina, estrógenos, fatores locais como o EGF, ILl, TNF, prostaglandinas.

Prof. Richieri-Costa: É um modelo curioso e de predomínio de ação do ambiente sobre uma variável.

Prof. Maria Fernanda: Seria como o efeito do sol na pele.

Prof. Richieri-Costa: Na pele?

Prof. Maria Fernanda: Se você não fica no sol elimina a ação ambiente, cessa o efeito de escurecimento da pele.

Prof. Richieri-Costa: O efeito do sol na pele pode levar ao câncer.

Prof. Maria Fernanda: A longo prazo. 
Prof. Consolaro: A minha pele é muito branca, posso ter câncer se tomar muito sol. E no dente se eu tivesse raiz triangular, levaria à reabsorção dentária, se movimentasse ortodonticamente os dentes. A cor branca facilita a instalação do agressor. Então o dano não foi herdado, ele não tem predisposição genética ao dano, ele tem uma pele que é mais frágil à ação do quem tem pele mais escura e protegida pela melanina.

Prof. Richieri-Costa: Com essa cor eu nasci no país errado!

Prof. Consolaro: A pele clara, comparando com a ocorrência da reabsorção dentária, seria a raiz triangular. A pele escura para o sol, seria a raiz romboidal, que distribui melhor as forças. A melanina da pele escura bloqueia o ultravioleta e protege o núcleo da célula. Então ter lesão cancerosa de pele é uma conseqüência ambiental. A lesão em si não é hereditária, o que é hereditário é a cor da pele, como a forma da raiz.

Prof. Richieri-Costa: Muito bem, a cor da pele. Então, sabendo disso eu posso prever?

Prof. Maria Fernanda: Mas nenhum programa de prevenção de câncer lançou uma vinheta do tipo: a pele branca tem "predisposição genética" para câncer de pele. Mas sim: previna-se, evite sol em excesso, nas horas tais e tais, use protetor solar...

Prof. Consolaro: O Ortodontista ao verificar a forma da raiz pode decidir: neste caso eu tenho que ir mais devagar, redimensionar o planejamento...

Renata B. Consolaro: E no caso dos dentes com hipercementose?

Prof. Consolaro: Ninguém estudou dentes com hipercementose em movimentos ortodônticos, exageradamente rombóides. É um trabalho que estamos para fazer.

Prof. Consolaro: A reabsorção dentária é mediada por vários produtos, entre os quais a IL. O polimorfismo que existe na transmissão dos genes para as interleucinas, seria suficiente para explicar mais ou menos reabsorção em um determinado paciente? Só estudar o polimorfismo dos genes de um desses mediadores, seria suficiente para concluir que certos pacientes, com certos alelos teriam mais reabsorção?

Prof. Richieri-Costa: Eu não sei. Mas é tentador. Prof. Consolaro: Mesmo sendo muitos mediadores associados?

Prof. Richieri-Costa: Mesmo sendo muitos. Agora é aí que a gente volta a falar dos trios, ou seja estudos envolvendo apenas os pais e filhos. Você não vai ter resposta se tiver só o paciente isolado. Entende? Então, o que seria o ideal? Eu tenho um pai que, por alguma razão qualquer não tem reabsorção aumentada, a mãe é normal e o filho com dezessete, dezoito anos tem reabsorção aumentada. Esse trio é interessante, porque o isolado não informa. $\mathrm{O}$ isolado não é informativo, eu não tenho comparação. Eu não vou conseguir dizer: Este tem mais esse alelo, ele tem mais aquele alelo, entende? Como são multifatoriais, são sistemas, as diferenças são muitas. Porque eu posso combinar o alelo A com o alelo D, e os outros alelos estão todos ali. Mas com uma freqüência está perto de um polimorfismo. Então é difícil! É um trabalho tentador, mas é quebrar pedra dura. É difícil de interpretar. Essas cascatas são sistemas de muitos genes, muitos alelos. Qual é a combinação da chave que dá o fenômeno? É difícil!

Tudo isso teria que ser aliado a uma metodologia de diagnóstico das reabsorções dentárias com muita precisão. São muitas variáveis próprias que você vai ter que considerar. E depois o sistema! Então na verdade, você vai trabalhar com dois grandes grupos de variáveis. Eu não invejo quem vai trabalhar com isso. A dificuldade já começa em selecionar as amostras. Selecionar trios é difícil.

Prof. Maria Fernanda: É difícil porque você deveria ter as mesmas características do pai no filho, por exemplo, o pai deveria ser tratado ortodonti- 
camente e também o filho e ambos terem sofrido reabsorção radicular.

Prof. Richieri-Costa: Ou a mãe.

Prof. Consolaro: Então seria complicado concluir só a partir de um polimorfismo dos alelos de um dos mediadores, mesmo com critérios diagnósticos bem precisos?

Prof. Richieri-Costa: Vários mediadores, dependem de genes homeobox e são extremamente complexos. Essas superfamílias de genes são difíceis de trabalhar em função disso.

Prof. Consolaro: Então, considerando isso, podemos dizer que pessoas com diabetes ou fissura labiopalatal, que são heranças multifatoriais, podem ser "predispostas" a ter essas doenças? Poderíamos deixar os termos "fatores predisponentes" para questões de hereditariedade genética ou não? Estes termos podem ser usados indiscriminadamente?

Prof. Richieri-Costa: Parece claro que isto tudo não é predisposição, é risco. Quanto às fissuras labiopalatais deve-se perguntar: Estou em risco de ter filhos com esta alteração? E então concluir: Se eu venho de uma família, em que existem vários afetados com fissuras, por exemplo, eu tenho até como prever um risco aproximado. Prefiro falar em risco em vez de fator predisponente. O termo predisponente é muito vago.

Prof. Consolaro: Se eu digo ao paciente: você tem um fator predisponente à reabsorção dentária ou, você tem um fator genético, ou um fator hereditário. Devo encaminhá-lo ao geneticista?

Prof. Richieri-Costa: Ou provar que tem um fator genético atuando. Senão é complicado! Aqui no Centrinho aparecem coisas absurdas! Pacientes chegam e dizem: doutor, tal coisa é assim? Eu digo: me dê uma semana? Eu venho aqui, faço todo o levantamento, não tem nada parecido na literatura. Eu não tenho elementos para dizer se é ou não hereditário.

Hoje, se vier alguém com reabsorção dentária aqui e me perguntar, eu digo: olha, me dá uma semana? Ou, eu não tenho elementos para dizer. Tem tais trabalhos que dizem que não tem nada a ver com a genética, é só ambiental. Agora, tem um ou outro trabalho que diz que em amarelo é mais comum que em branco, que em índio é mais comum que em esquimó, ou que só esquimó tem caráter familial, por exemplo e hipoteticamente. Enfim, a informação que eu vou dar é a informação técnica baseada em evidências. Porque senão, não estou sendo honesto. E estou chutando, falando uma besteira. É muito comum você ver por aí alguma coisa que não se consegue explicar e então alguém pergunta: seu pai tinha? Tinha. Então é genético. Então porque seu pai teve é genético? Não, porque seu pai teve absolutamente não significa que seja genético ou hereditário.

Prof. Consolaro: Você concorda com afirmações como: Hoje em dia a genética explica tudo?

Prof. Richieri-Costa: Não. Circuncisão não é genética, e todo homem judeu é circuncisado.

Prof. Consolaro: Existe algum banco de dados que se possa acessar e encontrar estudos genéticos sobre um assunto específico de genética, ou a busca segue os sistemas de referências usados para todas as áreas?

Prof. Richieri-Costa: No nível da biologia molecular temos muitos bancos de dados. Como foram criados esses bancos? Por causa do interesse. A hora que você falar que tem um esporão aqui e mandar para aquele determinado banco de dados e perguntar: você determina o meu interesse no cromossomo tal gene pra mim? Eles vão fazer e vão segurar o sangue do paciente, eles vão criar um banco disso. Eles ainda não sabem o que é, mas eles têm um banco lá. 
Prof. Consolaro: Mas esse acesso é público?

Prof. Richieri-Costa: É publico, paga-se, mas é público. Então você tem as facilities nos Estados Unidos, se você tiver o sangue a facilitie faz lá o seqüenciamento que você quiser. Cobram e devolvem os dados, é uma questão de saber interpretar os dados e isso nem sempre é fácil. Então, o conveniente de ter um bom geneticista molecular, é que ele faz isso para você. Mas existem os bancos que inclusive fazem os primers dessa seqüência.

Prof. Consolaro: Uma última pergunta. Estou lendo um trabalho que implica hereditariedade na reabsorção, mas pode seria ser na osteoporose, na cor do cabelo, etc. Quais são os critérios necessários para analisar um trabalho cientifico e considerá-lo válido como pesquisa genética e sobre hereditariedade?

Prof. Richieri-Costa: Checar a metodologia sempre. Um trabalho tem valor quando tem uma metodologia adequada. Trabalho sem metodologia não é trabalho, é saque. O saque pode ser bom? Até pode. Mas é extremamente sujeito à paulada, não é? Agora, quando se tem um trabalho metodologicamente perfeito, cercadinho, bonitinho e você mostra que essa mancha branca no dente é isso por causa daquilo, acabou. Ninguém desata esse nó, está comprovado. Agora dizer assim: Ah! esqueci de perguntar se fumava. Ah! esqueci de perguntar se existia algum distúrbio metabólico X na família! Esqueci aquilo! Ah, mas eu não vi bem isso! Quando você chega no final, não tem resultado. O trabalho é bonito, três, quatro da família têm, você acha que é isso. Mas você tem certeza? Ah, mas eu não li isso, eu não vi aquilo, eu não medi uma coisa, eu não dosei outra, tinha um irmão que tinha uma determinada doença, será que isso pode dar mancha branca?

Prof. Consolaro: Sendo mais específico, é possível fazer trabalhos e conseguir evidências de heredi- tariedade e genética hoje, só com heredogramas e sem a biologia molecular, por exemplo?

Prof. Richieri-Costa: Nós fazíamos isso até quinze, vinte anos atrás. É possível, claro que é possível! Agora, dentro de parâmetros bem definidos. Com amostras bem padronizadas. Temos um exemplo clássico aqui no Centrinho de uma síndrome rara, tem um ou dois casos publicados. Uma fenda de mandíbula que aqui chamamos de "Veroniquinhas", porque a primeira menina chamava Verônica e isso faz muito tempo.

Nós selecionamos e avaliamos mais de mil pacientes com fissuras. "Olha que menininha interessante?" - fomos deixando seu prontuário separado. E vendo prontuários, mais prontuários e o outros casos acumulando... Todas tinham a mesma coisa, nunca descrita na literatura. E olha que era uma fissura de mandíbula, muito rara, extremamente rara. Resultado: fizemos o levantamento. A maioria dos pais eram primos. A maioria deles vinham do Vale do Ribeira do Iguape e se diziam não aparentados. Fomos lá e ligamos todas as famílias. Eram parentes. Então, esse é um exemplo de um levantamento retrospectivo por heredograma e depois por campo. Bem padronizado e bem organizado.

Prof. Consolaro: E também deve ter trabalhos que apesar de usar biologia molecular, não foram criteriosos e não serviam para nada... Por fim, suas considerações finais?

Em caso de dúvida, consulte um advogado!

Equipe responsável pela viabilização desta entrevista:

Prof. Dr. Alberto Consolaro - Professor Titular em Patologia da FOB-USP Profa.Maria Fernanda Martins-Ortiz - Ortodontista e Doutoranda em Patologia Bucal na FOB-USP

Profa.Patrícia Zambonato Freitas - Ortodontista do Centrinho e Doutoranda em Patologia Bucal na FOB-USP

$C D$ Renata Bianco Consolaro - Mestranda em Patologia Bucal

CD Carlos Henrique Bettoni Cruz de Castro - Residente em Cirurgia Bucomaxilofacial no Hospital de Reabilitação de Anomalias Craniofaciais da Universidade de São Paulo. 